\title{
Radiation-induced spinal nerve root cavernous malformations as a rare cause of radiculopathy
}

Figure $1 \quad$ MRI lumbar spine

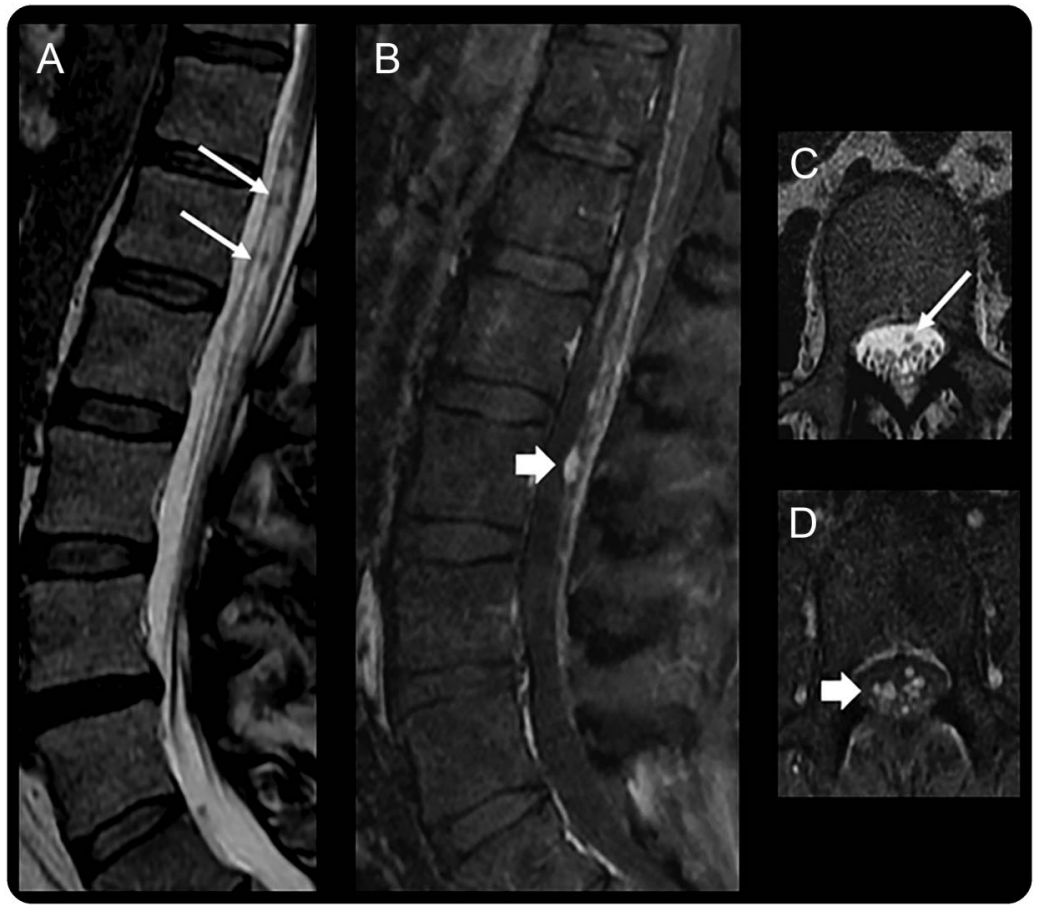

(A) Sagittal T2; (B) sagittal T1 postcontrast; (C) axial T2; (D) axial T1 postcontrast. MRI lumbar spine demonstrates numerous small nodules (arrows, A and C) along the cauda equina with enhancement (arrowheads, B and D).

A 48-year-old man with Hodgkin lymphoma presented with insidious painless asymmetric ankle then thigh weakness 16 years after mantle-field radiation. EMG was consistent with a motor lumbosacral polyradiculopathy. CSF had 15 white blood cells $/ \mu \mathrm{L}$, protein $387 \mathrm{mg} / \mathrm{dL}$, and normal glucose. Nodular enhancing lesions were seen on lumbar MRI (figure 1). Caudal root biopsy demonstrated mulberry-shaped vascular abnormalities (figure 2) and thickened endoneurial vessel walls without inflammation. Workup for leptomeningeal
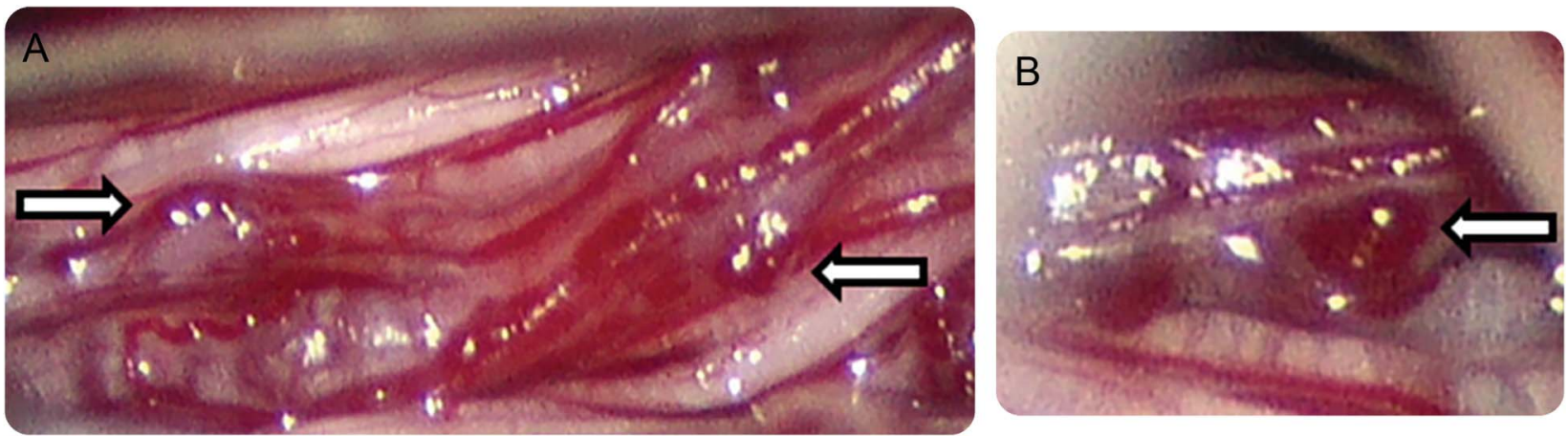

Intradural exploration photomicrographs demonstrate small mulberry-shaped, vascular malformations along the cauda equina (arrows) consistent with radiation-induced cavernous malformations. 
carcinomatosis and inflammatory and infectious disease was negative. High-dose steroids produced no clinical improvement. A diagnosis of radiation-induced cavernous malformations, a rare complication of radiation previously reported in the cauda equina, was made. ${ }^{1,2}$

Komal Rastogi, MD, Christopher J. Klein, MD, John E. O'Toole, MD, Miral D. Jhaveri, MD, Rabia Malik, MD

From the Departments of Neurological Sciences (K.R., R.M.), Neurosurgery (J.E.O.), and Radiology and Nuclear Medicine (M.D.J.), Rush University Medical Center, Chicago, IL; and Department of Neurology (C.J.K.), Mayo Clinic, Rochester, MN.

Author contributions: Komal Rastogi: study concept and design, acquisition of data, critical revision of manuscript for intellectual content. Christopher J. Klein: study concept and design, acquisition of data, critical revision of manuscript for intellectual content. John E. O'Toole: acquisition of data, critical revision of manuscript for intellectual content. Miral D. Jhaveri: study concept and design, acquisition of data, critical revision of manuscript for intellectual content. Rabia Malik: study concept and design, acquisition of data, critical revision of manuscript for intellectual content.

Study funding: No targeted funding reported.

Disclosure: The authors report no disclosures relevant to the manuscript. Go to Neurology.org for full disclosures.

Correspondence to Dr. Rastogi: komalrastogi@gmail.com

1. Nimjee SM, Powers CJ, Bulsara KR. Review of the literature on de novo formation of cavernous malformations of the central nervous system after radiation therapy. Neurosurg Focus 2006;21:e4.

2. Drazin D, Kappel A, Withrow S, Perry T, Chu R, Phuphanich S. Post-irradiation lumbosacral radiculopathy associated with multiple cavernous malformations of the cauda equina: case report and review of the literature. Surg Neurol Int 2017;8:26.

\section{WriteClick ${ }^{\circledR}$ rapid online correspondence}

Have a comment on a recent $N e u r o l o g y{ }^{\circledR}$ article you would like to share? Now it is easier and more convenient. Neurology. org has launched WriteClick on the home page and sidebars of each article to encourage remarks and debate among users.

WriteClick is restricted to comments about studies published in Neurology within the last eight weeks.

Learn more at Neurology.org/letters

\section{Minutes Pack a Punch}

\section{Neurology ${ }^{\circledR}$ Podcasts}

- Interviews with top experts on new clinical research in neurology

- Editorial comments on selected articles

- Convenient-listen during your commute, at your desk, or even at the gym

- On demand-it's there when you want it

- Fun and engaging

- New topic each week

- FREE

Listen now at www.aan.com/podcast 


\section{Neurology}

\section{Radiation-induced spinal nerve root cavernous malformations as a rare cause of radiculopathy}

Komal Rastogi, Christopher J. Klein, John E. O'Toole, et al.

Neurology 2017;89;2299-2300

DOI 10.1212/WNL.0000000000004693

This information is current as of November 27, 2017

\section{Updated Information \&} Services

References

Subspecialty Collections

Permissions \& Licensing

Reprints including high resolution figures, can be found at: http://n.neurology.org/content/89/22/2299.full

This article cites 2 articles, 0 of which you can access for free at: http://n.neurology.org/content/89/22/2299.full\#ref-list-1

This article, along with others on similar topics, appears in the following collection(s):

All Clinical Neurology

http://n.neurology.org/cgi/collection/all_clinical_neurology All Neuromuscular Disease

http://n.neurology.org/cgi/collection/all_neuromuscular_disease

All Oncology

http://n.neurology.org/cgi/collection/all_oncology

\section{All Spinal Cord}

http://n.neurology.org/cgi/collection/all_spinal_cord

MRI

http://n.neurology.org/cgi/collection/mri

Information about reproducing this article in parts (figures,tables) or in its entirety can be found online at:

http://www.neurology.org/about/about_the_journal\#permissions

Information about ordering reprints can be found online:

http://n.neurology.org/subscribers/advertise

Neurology ${ }^{\circledR}$ is the official journal of the American Academy of Neurology. Published continuously since 1951, it is now a weekly with 48 issues per year. Copyright @ 2017 American Academy of Neurology. All rights reserved. Print ISSN: 0028-3878. Online ISSN: 1526-632X.

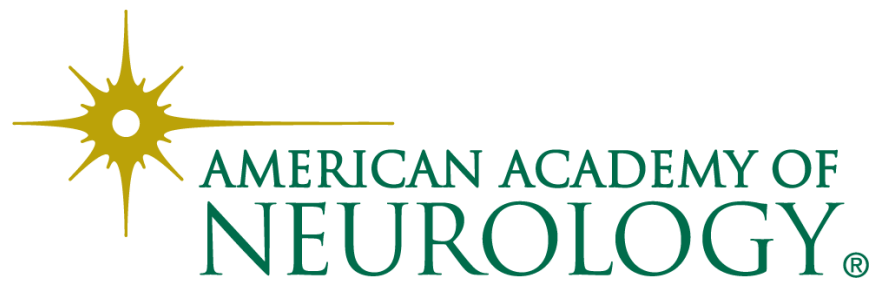

